\title{
Kennis over en gebruik van professionele echtscheidingsbemiddeling in het licht van de wet van 18 juli 2006
}

\author{
Inge Pasteels ${ }^{1}$, Sam Smit ${ }^{1}$, Kim Bastaits ${ }^{1}$, Dimitri Mortelmans ${ }^{1}$ \\ 1 Universiteit Antwerpen
}

\begin{abstract}
Sinds 2001 is professionele echtscheidingsbemiddeling wettelijk erkend als mogelijk onderdeel van een echtscheidingsprocedure. Op basis van gegevens van het project "Scheiding in Vlaanderen" gaan we na wie op de hoogte is van de mogelijkheid tot bemiddeling en wie er vervolgens ook gebruik van maakt. Hierbij hebben we aandacht voor de wetswijziging van 18 juli 2006 die de rechter verplicht ouders die gaan scheiden te informeren over professionele echtscheidingsbemiddeling. Uit de resultaten blijkt dat hoogopgeleiden vaker professionele echtscheidingsbemiddeling kennen. Professionele echtscheidingsbemiddeling vervolgens ook gebruiken komt meer dan gemiddeld voor wanneer de vrouw van het ex-koppel hoger opgeleid is. Bovendien is de doelgroep die in het vizier was door de wet van 2006 bereikt. Ouders zijn na de wetswijziging meer op de hoogte van professionele echtscheidingsbemiddeling dan andere (ex-)koppels. Gezien er een duidelijk effect te merken is van de informatieverstrekking door rechters op het kennen van bemiddeling lijkt het aangewezen de informatieplicht te veralgemenen. Meer nog echter lijkt het aangewezen professionele echtscheidingsbemiddeling te integreren in een ruimer aanbod van echtscheidingszorg waarin alle relevante organisaties krachten bundelen om geïnformeerde keuzes en kwaliteitsvolle echtscheidingstrajecten na te streven.
\end{abstract}

\section{INLEIDING}

In België is het aantal echtscheidingen in de laatste dertig jaar verviervoudigd (ADSEI, 2010) en worden huwelijken steeds sneller ontbonden (Mortelmans, 2011). In 2012 werden 26.145 echtscheidingen geregistreerd (ADSEI, 2012). Niet alleen het gescheiden zijn, maar ook het scheidingsproces kan negatieve gevolgen hebben voor de betrokken personen (Vander Steene, 2007). Bovendien treft het ontbinden van een huwelijk meer personen dan enkel het (ex-)koppel. Onderzoek m.b.t. het echtscheidingsproces is voor steeds meer (toekomstige) ex-partners en andere betrokken partijen relevant. Ook de voordelen van een vlotte en conflictloze echtscheiding voor de gehele samenleving, met name voor het gerecht en voor ondersteunende maatschappelijke diensten, mogen niet onderschat worden.

De wetgever tracht sinds de jaren '90 door opeenvolgende wetswijzigingen het echtscheidingsproces te optimaliseren. Sinds 2000 werd er een nieuw instrument in het echtscheidings- 
proces geïntroduceerd: de professionele echtscheidingsbemiddeling. Bemiddeling werd in het wetsvoorstel (2003-2004) beschreven als "een proces van overleg tussen conflicterende partijen, dat wordt geleid door een onafhankelijke derde die de communicatie vergemakkelijkt en poogt de partijen er toe te brengen zelf tot een oplossing te komen". Dit komt overeen met de internationaal gangbare definitie (Daniëls, Taelman, \& Buysse, 2010). Andere bronnen integreren expliciet positieve eigenschappen in de definitie van bemiddeling zoals het verbeteren van communicatie, samenwerking en het verminderen van conflict (Tishler, Landry-Meyer, \& Bartholomae, 2003; Walton, Oliver, \& Griffin, 1999).

Met de wet van 19 februari 2001 inzake de proceduregebonden bemiddeling in familiezaken werd professionele echtscheidingsbemiddeling voor het eerst wettelijk geregeld in België (Wet, 19 februari 2001). Later werd deze wet opgeheven en geïntegreerd in de wet van 21 februari 2005 (Wet, 21 februari 2005). Bij deze laatste wetswijziging werd bemiddeling een wettelijk erkende methode van geschiloplossing naast de gerechtelijke methode. Tevens werd er een federale bemiddelingscommissie opgericht die instaat voor de erkenning en controle van de bemiddelaars en hun opleidingen (Daniëls \& Buysse, 2010). Sinds de wet van 18 juli 2006 tot het bevoorrechten van een gelijkmatig verdeelde huisvesting van het kind van wie de ouders gescheiden zijn en tot regeling van de gedwongen tenuitvoerlegging inzake huisvesting van het kind is de rechter verplicht om koppels te informeren over het bestaan van bemiddeling in familiezaken in verband met ouderlijk gezag en contact met minderjarige kinderen: "Onverminderd artikel 1734 van het Gerechtelijk Wetboek, poogt de rechtbank de partijen te verzoenen. Zij verstrekt hen alle nuttige inlichtingen over de rechtspleging en in het bijzonder over het nut een beroep te doen op de in het zevende deel van het Gerechtelijk Wetboek bepaalde bemiddeling. Indien zij vaststelt dat een toenadering mogelijk is, kan

\section{Over het onderzoek Scheiding in Vlaanderen (SIV)}

SiV-data zijn afkomstig van het onderzoek "Scheiding in Vlaanderen". In dit onderzoek werd via een interview informatie verzameld bij beide partners van eerste huwelijken die afgesloten zijn tussen 1971 en 2008 en intussen al dan niet ontbonden zijn. Ook een kind, een ouder en een eventuele nieuwe partner van deze personen werden indien mogelijk bevraagd. Zij kregen een schriftelijke vragenlijst of websurvey aangeboden. De gegevens zijn verzameld in de periode van september 2009 tot december 2010.
12110 van alle 26376 gecontacteerde personen konden bevraagd worden wat een totale respons van $46 \%$ oplevert voor deze multi-actorstudie over huwelijk en echtscheiding. Gedetailleerde informatie over dit onderzoek en deze dataverzameling vindt $u$ op www.scheidinginvlaanderen.be en in het boek: Mortelmans Dimitri, Pasteels Inge, Bracke Piet, Matthijs Koen, Van Bavel Jan, Van Peer Christine (2011) Scheiding in Vlaanderen. ISBN 978-90-334-85862 - Leuven: Acco, 355 p. 
zij de schorsing van de procedure bevelen, teneinde de partijen de mogelijkheid te bieden alle nuttige inlichtingen hierover in te winnen en het bemiddelingsproces op te starten. De duur van de schorsing mag niet meer dan één maand bedragen." (Bastaits, Van Peer, Alofs, Pasteels, \& Mortelmans, 2011; Wet, 18 juli 2006).

Recent komt ook in onderzoek professionele echtscheidingsbemiddeling steeds meer aan bod. Eerste cijfers gebaseerd op de data van "Scheiding in Vlaanderen (SiV)", wijzen erop dat de kennis aangaande professionele echtscheidingsbemiddeling toeneemt van $65,5 \%$ (voor de wet van juli 2006) naar 68,3\% (na de wet van juli 2006) (Bastaits, Van Peer, Alofs, Pasteels, \& Mortelmans, 2011). Cijfers uit het "Interdisciplinair onderzoek naar de optimalisatie van scheidingstrajecten (IPOS)" geven een kennisgraad van $80 \%$ aan voor de periode tussen maart 2008 en maart 2009 (Daniëls, Taelman, \& Buysse, Bemiddeling, 2010). Beide onderzoeken geven aan dat maar een deel van deze personen ook effectief gebruik maakt van professionele echtscheidingsbemiddeling (Bastaits, Van Peer, Alofs, Pasteels, \& Mortelmans, 2011; Daniëls, Taelman, \& Buysse, 2010; Vander Steene, 2007). Gescheidenen voor en na de wet van juli 2006 maken respectievelijk $18,9 \%$ en $23,7 \%$ gebruik van professionele echtscheidingsbemiddeling (Bastaits, Van Peer, Alofs, Pasteels, \& Mortelmans, 2011).

Er kan verondersteld worden dat het ontbreken van kennis en het uitblijven van het gebruik van professionele echtscheidingsbemiddeling eigen is aan bepaalde groepen in de samenleving. Van der Steene (2007) focust in haar onderzoek op de toegankelijkheid van hulpverlening in scheidingssituaties (waaronder bemiddeling) voor bepaalde doelgroepen. Zij evalueert de kwaliteit van de hulpverlening op basis van de 5B's (bereikbaarheid, beschikbaarheid, begrijpbaarheid, bruikbaarheid en betaalbaarheid) en geeft aan dat hulpverlening de sociaaleconomisch zwakkeren minder bereikt. Ander onderzoek toonde een positief verband tussen inkomen (Daniëls \& Buysse, 2010) en opleidingsgraad (Kelly, 2004) enerzijds en het gebruik van bemiddeling anderzijds aan.

Nationaal noch internationaal werd echter recent en op basis van populatiegebaseerde data onderzocht welke personen heden al dan niet bereikt worden door professionele echtscheidingsbemiddeling. Deze bijdrage komt tegemoet aan deze lacune in onderzoeksliteratuur door een antwoord te bieden op twee onderzoeksvragen. Ten eerste beschrijven we welke individuele kenmerken de kans om professionele echtscheidingsbemiddeling te kennen, bevorderen dan wel belemmeren. Voor de groep van de personen die professionele echtscheidingsbemiddeling kennen, bestuderen we vervolgens wie eerder wel respectievelijk eerder niet geneigd is bemiddeling tot deel van het scheidingsproces te maken. Aangezien zowel de kennis over als het gebruik van echtscheidingsbemiddeling toeneemt over de tijd (Bastaits, Van Peer, Alofs, Pasteels, \& Mortelmans, 2011), onderscheiden we verschillende scheidingscohorten om de determinanten van gebruik te onderscheiden. We gaan hierbij na hoe naast individuele kenmerken mogelijk ook de wet van juli 2006 een invloed had op het kennen alsook op het gebruiken van professionele echtscheidingsbemiddeling.

De hypothesen die we vooropstellen steunen op de innovatie-diffusietheorie van Rogers (2003) alsook op het gezondheidsgedragsmodel of "Behavioral Model of Health Services Use" van Andersen (1995). De eerste theorie kan inspirerend zijn wanneer we professionele echtscheidingsbemiddeling als een innovatieve 
component in het echtscheidingsproces beschouwen, om de tweede theorie toepasselijk te maken durven we veronderstellen dat echtscheidingsbemiddeling als een vorm van professionele doch niet-medische zorg gelijkenissen kan vertonen met gezondheidszorg wat het gebruik ervan betreft. Beide theorieën laten toe het differentieel kennen van maar vooral de verschillende mate van gebruik van professionele echtscheidingsbemiddeling vanuit individuele kenmerken te duiden.

De relevantie van deze studie is tweeërlei. Vooreerst zijn professionele echtscheidingsbemiddelaars gebaat met inzichten omtrent het profiel van mensen in scheiding die ze niet bereiken om hun dienstverlening in het licht hiervan te evalueren en te optimaliseren. Belangrijker echter zijn de ex-partners zelf. De bevinding dat zelfbeschikking in scheidingstrajecten uitermate belangrijk is met het oog op het welzijn van de betrokkenen maakt deze studie immers ook voor hen uitermate relevant. Zelf een weloverwogen en geïnformeerde keuze maken voor het ene dan wel het andere scheidingstraject verhoogt de tevredenheid van de ex-partners (Buysse, 2011). Voor het relatief grote aantal ex-partners die aangeven professionele echtscheidingsbemiddeling niet te kennen kan het gekozen traject voor een alternatief echtscheidingstraject nooit een optimaal geïnformeerde keuze zijn aangezien ze op het moment van de beslissing niet beschikten over enige kennis omtrent professionele echtscheidingsbemiddeling.

\section{THEORIE}

\subsection{Professionele eChTSCHEIDINGS- BEMIDDELING ALS INNOVATIE IN HET ECHTSCHEIDINGSPROCES}

De innovatie-diffusietheorie, ontstaan in 1962 en verder ontwikkeld in de decennia nadien, verklaart hoe, waarom en hoe snel nieuwe ideeën zich kunnen verspreiden door een sociaal systeem (Rogers, 1962,1983,1995, 2003; Rogers, E. M., Shoemaker, F.,1971). Alhoewel aanvankelijk ontstaan in het licht van de verspreiding van nieuwe technologieën, zijn er in recent werk omtrent social change ook telkens verwijzingen naar deze theorie en het bijhorend begrippenkader (Hoffman, 2011; Les Robinson, 2012).

Essentieel aan de innovatie-diffusietheorie is de tijdsdimensie. De theorie maakt een onderscheid tussen personen op basis van het tempo waarmee ze gebruik maken van een innovatie. Rogers (2003) beschrijft in de meest recente editie van zijn 'diffusion of innovations' vijf 'adopter' categorieën op basis van hoe snel zij zich een innovatie eigen maken, met name "innovators", "early adopters", "early majority", "late majority" and "laggards", die 2,5\%, $13,5 \%, 34 \%$, 34\% respectievelijk $16 \%$ van de populatie uitmaken. Wanneer een innovatie nog niet uitgebreid en langdurig getest is door een grote groep personen blijft er steeds een zekere onzekerheid/risico aan verbonden waardoor enkel de groepen die het meest risicotolerant zijn, zich de nieuwigheid eigen maken. Hoe langer een innovatie bestaat en hoe meer deze gebruikt wordt, hoe meer mensen geïnformeerd zullen zijn over een nieuwigheid en de eventuele kosten en baten ervan. Deze ruimere verspreiding van relevante informatie 
zal vervolgens leiden tot het gebruik van de innovatie door minder snelle 'adopter' categorieën. Uiteindelijk leidt dit proces naar een totale integratie van de innovatie in het sociale systeem. Het is enkel in de beginjaren dat er een duidelijk onderscheid te merken is tussen verschillende 'adopter' categorieën doordat de ene groep zich de innovatie sneller eigen maakt dan de andere groep.

Zich een innovatie eigen maken heeft te maken met enerzijds de toegang tot informatie en de bereidwilligheid om te zoeken naar deze informatie (kennen), anderzijds met de motivatie om de innovatie effectief toe te passen (gebruiken). Specifieke kenmerken van een persoon bepalen in welke mate iemand sneller over meer en vooral over meer juiste informatie kan beschikken. Uiteraard is het kennen van een innovatie de eerste vereiste om deze ook effectief te gebruiken. We durven veronderstellen dat iemands economisch, cultureel en sociaal kapitaal en bijhorende levensstijl kunnen bepalen of men al dan niet weet heeft van een specifieke nieuwigheid die een bepaalde sociale groepering meer of minder typeert.

Wat de motivatie betreft om een innovatie te gebruiken, beschrijft Rogers (2003) enerzijds het risico en anderzijds de risicotolerantie. De beschikbaarheid van meer en betere informatie zorgt ervoor dat het genomen risico bij het gebruik van de innovatie afneemt. Een goed geïnformeerde persoon neemt immers een kleiner risico aangezien de gevolgen van het gebruik van de innovatie beter voorspeld kunnen worden. Doordat er steeds een zeker risico verbonden is aan het gebruik van een innovatie is ook een tweede factor belangrijk in de keuze omtrent het al dan niet gebruiken van de innovatie. De risicotolerantie bepaalt in welke mate een persoon of een groep personen een buffer heeft om mogelijk negatieve gevolgen van het gebruik van de innovatie op te vangen.

In tegenstelling tot het risico dat wijst op de beperkte informatie die beschikbaar is over de innovatie, zijn er ook steeds gekende voor- en nadelen aan het gebruiken van de innovatie. Wejnert spreekt in haar artikel over kosten en baten (Wejnert, 2002) als het gaat over de uiteindelijke keuze om de innovatie te gebruiken. Deze voor- en nadelen zijn, in tegenstelling tot het risico, steeds gebaseerd op de beschikbare informatie. Door de persoonlijke situatie kan het zijn dat er meer of minder voor- en/of nadelen verbonden zijn aan het gebruik van de innovatie.

Het relatieve voordeel is een van de vijf specifieke kenmerken van een innovatie die Rogers (2003) essentieel acht met het oog op de verspreiding ervan. Het relatieve voordeel kan een economisch voordeel zijn maar ook prestige, conformisme en tevredenheid kunnen als zodanig beschouwd worden. De verschillende "adopter" categorieën zullen mogelijke voordelen anders evalueren. Een tweede kenmerk betreft de compatibiliteit met bestaande waarden en praktijken. Enige consistentie met eerdere ervaringen, specifieke waarden en bestaande praktijken vergemakkelijkt dat een innovatie ingang vindt. Eenvoudig en makkelijk te gebruiken is een derde eigenschap. Ideeën die helder en eenvoudig zijn vinden makkelijker hun weg naar de eventuele gebruikers. De mogelijkheid om de innovatie uit te testen of om er mee te experimenteren vergemakkelijkt eveneens de verspreiding ervan. De laatste eigenschap betreft het bestaan van zichtbare resultaten. Zien wat werkt, scherpt uiteraard de geloofwaardigheid van een innovatie aan.

Professionele echtscheidingsbemiddeling is een relatief nieuwe manier voor koppels om 
hun echtscheiding te regelen en kan gezien worden als een innovatie in het echtscheidingsproces. Het echtscheidingsproces en bijgevolg ook het eventuele bemiddelingstraject heeft een zeer grote invloed op alle betrokken partijen. Dit maakt dat factoren als risico en risicotolerantie die verbonden zijn aan de professionele echtscheidingsbemiddeling uitermate relevant zijn om kennis over en gebruik van bemiddeling te begrijpen. Het kan daarnaast ook nuttig zijn de kenmerken van bemiddeling te beschouwen in het licht van deze innovatie-diffusietheorie.

\subsection{PROFESSIONELE ECHTSCHEIDINGS- BEMIDDELING: EEN VORM VAN PROFESSIONELE ZORGGEBRUIK BIJ ECHTSCHEIDING}

Alhoewel bemiddeling als professionele zorg uiteraard een niet-medisch karakter heeft, kan een gangbare theorie omtrent gebruik van professionele doch medische zorg zoals het gezondheidsgedragmodel van Andersen (1995) ook inspirerend zijn om verschillen inzake het gebruik van professionele echtscheidingsbemiddeling te voorspellen. Dit model onderscheidt in zijn eerste versie in '68 drie sets van determinanten die het gebruik van gezondheidsvoorzieningen bepalen: de zorgbehoefte ("need"), de neiging om zorg te zoeken ("predisposing characteristics") en de mogelijkheden ("enabling resources") om hulp te zoeken. Nadien breidt dit model zich uit in een tweede, derde tot een vierde versie waarbij in dit laatste model (Andersen, 1995) de kenmerken van het individu als verklaring gepositioneerd worden in een ruimer causaal schema. Hierin zijn ook kenmerken van het gezondheidssysteem ("health care system) en ruimere omgeving ("external environment") verklarende factoren voor gezondheidsgedrag ("health behavior") waarbinnen medisch zorggebruik ("use of health services") dan een component naast gezondheidspraktijken ("personal health practices") wordt. De gezondheidsstatus ("perceived health status" en "evaluated health status") alsook de tevredenheid met de verkregen zorg ("consumer satisfaction") zijn eveneens onderdelen van dit causale schema. Aangezien de empirische onderzoeksresultaten van deze bijdrage zich beperken tot een analyse van het gebruik ("usage") van professionele echtscheidingsbemiddeling focussen we voornamelijk op individuele kenmerken.

\section{LITERATUUR EN HYPOTHESEN}

Naar ons weten is er momenteel slechts in beperkte mate onderzoek gevoerd naar het naar individuele kenmerken gedifferentieerd gebruik van professionele echtscheidingsbemiddeling. Zoals aangegeven in vorige paragraaf inspireren we ons daarom op de theorie omtrent innovatie alsook op de theorie omtrent medisch zorggebruik. We gebruiken de theorievorming en hierop aansluitende empirische bevindingen uit deze belendende domeinen graag als aanvulling om enkele plausibele hypothesen omtrent de kennis over en het gebruik van professionele echtscheidingsbemiddeling te formuleren. Welke zijn met het oog op de professionele echtscheidingsbemiddeling de mogelijke invloedrijke factoren die kunnen bepalen of iemand snel over deze innovatie geïnformeerd is of die zich eigen maakt doordat het risico of de eigen risicotolerantie gunstig geëvalueerd worden? Of nog, welke factoren maken dat individuen eerder wél dan niet gebruik maken van een bestaand zorgaanbod inzake echtscheiding? In de hierna volgende paragrafen geven we waar mogelijk vanuit literatuur en theorie een motivatie voor de gekozen verklarende variabelen een bijhorende hypothese. 
De eerste set van variabelen onder beschouwing betreft sociaal-economische kenmerken. Eerder onderzoek toonde een positief verband aan tussen inkomen (Daniëls \& Buysse, Echtscheiding: (Echt)scheidingsbemiddeling, 2010) en opleidingsgraad (Kelly, 2004) enerzijds en het gebruik van bemiddeling anderzijds. Uit de innovatietheorie weten we dat personen met een hogere sociaal-economische status sneller, beter en meer toegang zullen hebben tot informatie aangaande innovatieve producten en diensten alsook een sterkere buffer kunnen opzetten tegen eventuele nadelen verbonden aan de innovatie dan personen die een lagere sociaal-economische status hebben (Rogers, 1983). Onderzoeken die peilen naar het zorggebruik bij huisartsen versus specialisten tonen aan dat, indien rekening gehouden wordt met gezondheidsverschillen, specialisten meer geconsulteerd worden door hoger opgeleiden dan door lager opgeleiden. Lager opgeleiden doen dan volgens de meeste studies weer vaker een beroep op de huisarts dan hoger opgeleiden. In meer algemene termen kunnen we uit deze onderzoeken mogelijk afleiden dat specialistische hulp meer hoogdrempelig lijkt te zijn des te lager men opgeleid is (Alonso, 2004; Bongers, e.a., 1997; De Graeve en Duchesne, 1997; De Prins, e.a., 1998; Gouwy et al., 2008; Mirowsky \& Ross, 1998 ; Svensson, Nygard, Sorensen, \& Sandanger, 2009; Vander Heyden, e.a., 2003; Van Der Meer e.a., 1996; Vasiliadis et al., 2009;) Op basis van deze resultaten verwachten we dat hoger opgeleiden meer dan lager opgeleiden professionele echtscheidingsbemiddeling kennen en gebruiken.

Als tweede set naast de sociaal-economische kenmerken kunnen ook relatiekenmerken voor de scheiding een invloed hebben op wat in de innovatietheorie de beschikbaarheid van de kennis over respectievelijk de verlaging van het risico en de verhoging van de risicotolerantie noemt. Hierbij denken we vooreerst aan een eventuele ervaring van een ouderlijke echtscheiding. Alhoewel een ouderlijke scheiding in recente huwelijkscohorten de eigen echtscheidingskans minder dan voorheen beïnvloedt (Corijn, Pasteels \& Mortelmans, 2012) kan de ervaring ervan mogelijk wel (nog) bepalend zijn om de kennis en meer nog het gebruik van bemiddeling te voorspellen. Het lijkt plausibel te veronderstellen dat de ervaring van een ouderlijke echtscheiding, mogelijk (v)echtscheiding, een scherpere noodzaak creëert om de eigen scheiding met professionele begeleiding aan te pakken, of nog dat bemiddeling eerder gekend is wanneer men niet alleen via de eigen relatie met echtscheiding te maken kreeg.

Ook brengen we de mate van geluk in het jaar voor het definitief apart gaan wonen in rekening. Deze factor wordt beschouwd als een indicator voor de mate waarin men een echtscheiding en de bijhorende bemiddeling aanvoelt als een logische oplossing voor een ervaren probleem. In het onderzoek van Cohen e.a. (2000) wordt er in deze context gesproken over 'toewijding tot echtscheiding'. Hoe zekerder over en meer toegewijd men is aan de echtscheiding, hoe meer voor de hand liggend het immers zal zijn in overleg te werken naar een gemeenschappelijk doel, de echtscheiding (Cohen, Luxenburg, Dattner, \& Matz, 2000) en hiervoor bemiddeling als nuttige methodiek te beschouwen. Analoog stellen we vanuit de theorie van Andersen dat de mate van geluk ervaren in het jaar voor het definitief apart gaan wonen, een indicator kan zijn voor de individuele behoefte ("need") die men voelt om via bemiddeling tot een scheiding te komen. Zij die minder gelukkiger waren het jaar voor de schei- 
ding, kunnen in deze optiek mogelijk meer tentakels richting professionele echtscheidingsbemiddeling gecreëerd hebben.

Ten derde kunnen via specifieke gezinskenmerken voor de scheiding meer voor- of nadelen gegenereerd worden door het gebruik van professionele echtscheidingsbemiddeling waardoor deze kenmerken bepalend zijn voor de kennis over of het gebruik van professionele echtscheidingsbemiddeling. Als er meer mogelijke voordelen verbonden zijn aan het gebruiken van de innovatie zal men sneller geneigd zijn deze personen te informeren over de innovatie of zullen personen zelf sneller informatie zoeken. Het principe van informatieverstrekking aan personen die er mogelijk een groter voordeel uithalen is immers reeds verankerd in de wet van 18 juli 2006. Voorgaand onderzoek toonde ook aan dat er meer koppels met kinderen dan zonder kinderen in bemiddeling zitten (Przybyla-Basista, 2008). We houden rekening met algemene relationele kenmerken zoals het hebben van gezamenlijke kinderen en een woning in gemeenschappelijke eigendom, aangezien we ervan uit gaan dat deze eigenschappen de kosten-batenanalyse voor het gebruik van bemiddeling beïnvloeden. Als dusdanig kunnen ook deze gezinskenmerken beschouwd worden als wat Andersen (1995) "predisposing characteristics" noemt. De kosten-batenanalyse kan de weegschaal in het voordeel van een keuze voor bemiddeling doen overhellen indien er kinderen en gemeenschappelijke eigendommen zijn.

\section{Relationele omgangskenmerken vlak na de} scheiding hebben eveneens een invloed op de kans om de voor- en nadelen van bemiddeling te bekomen. Een geslaagde professionele echtscheidingsbemiddeling genereert de verwachte voordelen, maar wanneer daarentegen de verhoopte resultaten in het bemiddelingsproces niet bereikt worden, wegen de nadelen eerder door. De subjectief gepercipieerde slaagkansen van bemiddeling zal bijgevolg de zoektocht naar informatie of de stap naar effectief gebruik van bemiddeling mede bepalen. Men kan verwachten dat de conflictgraad na de beslissing om definitief uit elkaar te gaan, de mate van communicatie na het definitief apart wonen en wie het initiatief nam om uit elkaar te gaan relevante invloedrijke factoren zijn inzake de subjectieve perceptie van ex-partners over het welslagen van de professionele echtscheidingsbemiddeling als mogelijke innovatie in het echtscheidingsproces.

Wat communicatie en conflict betreft kunnen we volgende hypothese naar voren schuiven. Uit onderzoek weten we dat een constructieve houding (Vandamme \& Evers, 2008), communicatie en conflict elementen zijn die de slaagkansen van bemiddeling sterk beïnvloeden (Cohen, Luxenburg, Dattner, \& Matz, 2000; Kelly J. B., 2004; Kelly J. B., 1996; PrzybylaBasista, 2008). Meer nog, bemiddeling wordt aanzien als een conflictreducerend en communicatiebevorderende methode (Kelly, 2004). De kwaliteit van de communicatie en het conflict, beschouwd als "enabling resource" respectievelijk "need", in rekening brengen sluit hierbij aan. Ex-partners kunnen immers op basis van de kwaliteit van hun huidige communicatie, alsook op basis van de mate van conflict, de slaagkans van bemiddeling voor henzelf inschatten en daarna al dan niet overgaan tot het verzamelen van informatie over bemiddeling of tot het gebruiken ervan. De hypothese hier zou zijn dat keuze voor bemiddeling meer aannemelijk wordt wanneer de communicatie tussen beiden ex-partners nog gaande is maar niet vanzelf vlot loopt, en dat het conflictgehalte toch niet dramatisch hoog is. 
Ook de mate waarin de man dan wel de vrouw het initiatief tot de echtscheiding nam, kan bepalend zijn om al dan niet te kiezen voor een bemiddelingstraject. Omdat de keuze voor bemiddeling ondersteund moet worden door beide partijen is het cruciaal dat zowel de man als de vrouw positief staan ten opzichte van professionele echtscheidingsbemiddeling. Aangezien de vrouw over het algemeen reeds positiever staat ten opzichte van bemiddeling (Ellis \& Stuckless, 1996), durven we veronderstellen dat als de man het initiatief tot echtscheiding neemt de kans groter zal zijn dat het koppel kiest voor bemiddeling. Ondanks dat vrouwen negatief staan ten aanzien van de echtscheiding wanneer zij de echtscheiding niet initiëren, zullen zij misschien nog wel positief staan ten opzichte van bemiddeling. Mannen daarentegen staan minder positief ten aanzien van bemiddeling, en zullen mogelijk niet snel geneigd zijn bemiddeling te gebruiken als zij ook nog eens niet akkoord gaan met de echtscheiding. De hypothese is dan ook dat bij een echtscheiding die enkel door de vrouw geinitieerd werd minder voor een bemiddelingstraject gekozen wordt dan wanneer de man eenzijdig of samen met de vrouw de beslissing nam te scheiden.

Vervolgens zijn er de echtscheidingsredenen die we als vijfde dimensie belangrijk achten ter verklaring. Deze kunnen immers aanzien worden als de problemen die er toe hebben geleid dat de relatie niet langer houdbaar was en tijdens het scheidingsproces een nood ("need") creëren om hulp te zoeken. De echtscheidingsredenen kleuren vaak de echtscheidingsdiscussie en kunnen bijgevolg eveneens de subjectief gepercipieerde slaagkansen van bemiddeling beïnvloeden of de noodzaak ervan motiveren. Het zelf ingeschatte risico dat bemiddeling zou falen of daarentegen heel erg nodig is, kan mensen zowel aanzetten om zich al dan niet te informeren als de ex-partners aanzetten om al dan niet in bemiddeling te gaan. Voorgaand onderzoek over dit verband is echter nog onbestaande waardoor we deze variabele eerder exploratief benaderen en voorafgaandelijk geen hypothese opstellen.

Tot slot nemen we geslacht, leeftijd bij scheiding en een tijdsvariabele als achtergrondkenmerken op. Wat geslacht betreft moeten we gegeven dat bemiddeling slechts gevolgd kan worden indien beide partners aanvaarden gebruik te maken van dit zorgaanbod rekening houden met actor- en partnereffecten. Empirische studies omtrent zorggebruik tonen aan dat vrouwen sneller geneigd zijn hulp te zoeken voor zichzelf dan mannen maar ook dat ze hun partners sneller stimuleren om hulp te zoeken (Colman, Symoens \& Bracke, 2011; Markey, Markey, Schneider, \& Brownlee, 2005; Umberson, 1987). Mannen daarentegen staan weigerachtig ten opzichte van het zoeken van hulp voor zichzelf en zullen ook zorggebruik door hun partner afraden. Een mogelijke verklaring is dat het zoeken van externe hulp bij problemen niet past bij hun stereotype mannelijke rol (Addis \& Mahalik, 2003; Gonzalez et al., 2011; Vollebergh et al., 2003). Reeds hoger gaven we aan dat eerder onderzoek reeds aantoonde dat vrouwen over het algemeen positiever staat ten opzichte van bemiddeling dan mannen (Ellis \& Stuckless, 1996). We verwachten dus dat vrouwen eerder dan mannen bemiddeling zullen aangeven bemiddeling te kennen. Wat het gebruik betreft, zal een zelfrapportering zoals hier geanalyseerd mogelijk eveneens leiden tot een genderverschil met het overwicht aan de kant van de vrouwen aangezien mannen misschien het gebruik van bemiddeling meer als een taboe ervaren. 
Hoe leeftijd bij scheiding en de kennis over of het gebruik van bemiddeling zich verhouden vinden we niet terug in het bestaande onderzoek. Wat mentale zorg betreft, weten we dat toenemende leeftijd samengaat met een afnemend zorggebruik (Kouzis \& Eaton, 1998). Gegeven de innovatietheorie lijkt het aannemelijk te stellen dat relatief jongere mensen meer toegang hebben tot of meer bereikbaar zijn voor innovatieve trajecten zoals bemiddeling. Of leeftijd bovenop hoger vermelde gezinskenmerken ook bepalend is om het risico en de risicotolerantie te bepalen laten we voorlopig in het midden.

Tot slot is er de tijdsdimensie die eigen is aan de innovatietheorie. Indachtig Rogers (2003) verwachten we een differentieel gebruik over de tijd. Professionele echtscheidingsbemiddeling is in België wettelijk geregeld sinds de wet van 19 februari 2001 aangaande de proceduregebonden bemiddeling in familiezaken (Wet, 19 februari 2001). Anno 2012 kunnen we dus tien jaar evolutie inzake bemiddeling bestuderen. Hierbij is rekening houden met de beleidscontext uiteraard essentieel. Sinds de wet van juli 2006 moeten scheidende ouders verplicht worden geïnformeerd door de rechter over de mogelijkheid tot professionele echtscheidingsbemiddeling (Wet, 18 juli 2006). Er zijn bijgevolg twee cohorten te onderscheiden, de personen gescheiden voor en na de wet van juli 2006, wanneer we de evolutie van de kennis over en het gebruik van professionele echtscheidingsbemiddeling bestuderen voor het afgelopen decennium.

\section{Data En MEthode}

De data gebruikt voor dit onderzoek zijn afkomstig van het onderzoek "Scheiding in Vlaanderen" (SiV). Om geclusterde informatie te vermijden, wordt er gebruik gemaakt van een subdataset met een toevallige selectie van één persoon voor de huwelijken waarvoor beide ex-partners geïnterviewd werden (Pasteels, Mortelmans, \& Van Bavel, 2011).

In deze bijdrage maken we enkel gebruik van de gegevens van ex-partners die gescheiden zijn na de wet van februari 2001. Enkel deze respondenten hadden wettelijk gezien de mogelijkheid professionele echtscheidingsbemiddeling minstens te kennen. De analyse omtrent de kennis over professionele echtscheidingsbemiddeling zal uitgevoerd worden voor 1.737 respondenten.

Aangezien professionele echtscheidingsbemiddeling enkel gebruikt kan worden indien het gekend is, wordt voor de onderzoeksvraag omtrent het al dan niet gebruiken van bemiddeling bovenstaande selectie verder verengd tot de personen die bemiddeling kennen. Na deze bijkomende restrictie houden we 1.152 respondenten over.

Bijlage 1 geeft een overzicht van alle variabelen die we gebruiken om de mogelijke invloedrijke factoren te operationaliseren. Tabel 3, eveneens in bijlage, geeft de beschrijvende statistieken voor deze variabelen weer.

Het dichotome karakter van de twee afhankelijke variabelen 'kennen' en 'gebruiken' impliceert het gebruik van logistische regressie. De verschillende sets van mogelijke invloedrijke factoren werden als verklarende variabelen stapsgewijs ingevoerd. Het gebruik van bemid- 
deling is in tegenstelling tot het kennen van bemiddeling, dat een individueel kenmerk is, een gezamenlijke eigenschap van de ex-partners. Daarom voegen we het opleidingsniveau van de ex-partner en informatie over wie initiatief nam om definitief uit elkaar te gaan toe aan deze verklaringsmodellen. We rapporteren enkel de odds-ratio's van de volledige modellen.

\section{Resultaten}

\subsection{WIE KENT PROFESSIONELE ECHTSCHEIDINGSBEMIDDELING?}

Twee derden $(66,4 \%)$ van alle respondenten gescheiden na februari 2001 heeft ooit gehoord van professionele echtscheidingsbemiddeling. In tabel 1 geven de oddsratio's aan

Tabel 1 Logistische regressie voor kennis over professionele echtscheidingsbemiddeling (oddsratio's)

Model $1 \quad$ Model $2 \quad$ Model $3 \quad$ Model 4

\begin{tabular}{|c|c|c|c|c|c|}
\hline \multirow[t]{2}{*}{ ACHTERGRONDKENMERKEN } & Geslacht (vrouw) & 0,898 & 0,898 & 0,970 & $0,643^{*}$ \\
\hline & Leeftijd bij scheiding & 1,001 & 0,985 & 0,996 & 1,017 \\
\hline COHORT & Cohort (na) & & 1,016 & & \\
\hline SOCIAAL - ECONOMISCHE & $\begin{array}{l}\text { Opleiding resp. } \\
\text { (hoger sec) }\end{array}$ & $1,726 * * *$ & $1,724 * * *$ & $1,727 * * *$ & $2,137 * *$ \\
\hline \multirow[t]{2}{*}{ KENMERKEN } & $\begin{array}{l}\text { Opleiding resp. } \\
\text { (voortgezet) }\end{array}$ & $4,082 * * *$ & $4,078 * * *$ & $4,032 * * *$ & $5,156 * * *$ \\
\hline & Activiteit (actief) & 0,881 & 0,881 & 0,842 & 1,153 \\
\hline \multirow{2}{*}{$\begin{array}{l}\text { RELATIEKENMERKEN VOOR } \\
\text { SCHEIDING }\end{array}$} & Geluk & 0,983 & 0,983 & 0,973 & 1,001 \\
\hline & Ouderlijke scheiding (ja) & 1,091 & 1,089 & 1,114 & 1,085 \\
\hline \multirow[t]{2}{*}{ GEZINSKENMERKEN } & Kinderen (kinderen) & 1,211 & 1,211 & 1,119 & $1,939 *$ \\
\hline & $\begin{array}{l}\text { Eigenaar } \\
\text { (gemeenschappelijk) }\end{array}$ & $1,263^{*}$ & $1,262^{*}$ & $1,269 *$ & 1,360 \\
\hline \multirow{3}{*}{$\begin{array}{l}\text { RELATIEKENMERKEN NA } \\
\text { SCHEIDING }\end{array}$} & Communicatie (matig) & $1,326 *$ & $1,326^{*}$ & 1,174 & $2,191 * *$ \\
\hline & Communicatie (slecht) & 1,130 & 1,129 & 1,009 & 1,675 \\
\hline & Conflict & 1,019 & 1,019 & $1,037^{* *}$ & 0,959 \\
\hline \multirow[t]{5}{*}{ ECHTSCHEIDINGSREDENEN } & Relatieproblemen & $1,361 * *$ & $1,361 * *$ & $1,482 * * *$ & 0,931 \\
\hline & Gedragsproblemen & 1,056 & 1,057 & 0,978 & 1,419 \\
\hline & Economische problemen & 1,137 & 1,137 & 1,242 & 0,904 \\
\hline & Ontrouw & 0,969 & 0,969 & 1,032 & 0,700 \\
\hline & Problemen met kinderen & 1,170 & 1,170 & 0,993 & $2,307^{*}$ \\
\hline \multicolumn{2}{|l|}{ Pseudo $\mathrm{R}^{2}$} & 0,10 & 0,10 & 0,11 & 0,16 \\
\hline \multicolumn{2}{|l|}{$\mathbf{N}$} & 1609 & 1609 & 1254 & 355 \\
\hline
\end{tabular}


welke verklarende variabelen als mogelijke invloedrijke factoren kunnen beschouwd worden m.b.t. het kennen van professionele echtscheidingsbemiddeling. We presenteren eerst twee geaggregeerde modellen over beide cohorten heen waarin we de tijdsvariabele die het behoren tot de vroege dan wel late scheidingscohorte weergeeft niet (model 1) en daarna wel (model 2) opnemen als verklarende variabele. Model 3 en 4 zijn dezelfde verklaringsmodellen, apart voor de gescheidenen van voor respectievelijk na de wet van 2006; dus behorend tot cohorte 1 respectievelijk cohorte 2 .

In model 1 wordt duidelijk dat er een sterk verband is tussen de opleidingsgraad van de respondent en het kennen van professionele echtscheidingsbemiddeling. Hoe hoger men opgeleid is, hoe beter men op de hoogte is van professionele echtscheidingsbemiddeling. Hoger opgeleiden hebben ongeveer vier keer meer kans om op de hoogte te zijn van professionele echtscheidingsbemiddeling dan lager opgeleiden. Voor de groep die hoger secundair onderwijs met succes voltooide is deze kans 1,7 keer hoger dan bij lager opgeleiden. Hoger opgeleiden hebben dankzij een hoger diploma duidelijk betere toegang tot informatie omtrent bemiddeling. De activiteitsstatus blijkt geen invloed te hebben.

Geen enkele van de relatiekenmerken voor scheiding zijn significant. Het hebben van gescheiden ouders heeft geen invloed op de kennis over professionele echtscheidingsbemiddeling. Ook het geluksgevoel in het jaar voordat men definitief apart ging wonen is niet bepalend voor het kennen van bemiddeling. In tegenstelling tot wat verwacht werd zijn personen die minder gelukkig waren in hun huwelijksrelatie en hierdoor mogelijk een grotere toewijding hadden tot de echtscheiding, niet beter op de hoogte zijn van de mogelijkheid tot professionele echtscheidingsbemiddeling.

Opmerkelijk is voorts dat het al dan niet hebben van kinderen geen invloed heeft. Ex-koppels zijn dan weer wel beter op de hoogte van professionele echtscheidingsbemiddeling als zij hun voormalige woning in gemeenschappelijke eigendom hadden. De kans om professionele echtscheidingsbemiddeling te kennen is voor koppels met een woning in gemeenschappelijke eigendom 1,263 keer groter dan bij koppels zonder woning in gemeenschappelijke eigendom.

Bij de gezinskenmerken is enkel de parameter voor de categorie 'matige communicatie' in vergelijking met 'goede communicatie' significant. Koppels die aangeven maximaal één keer per maand niet meer met elkaar te praten (matige communicatie) hebben 1,326 keer meer kans om bemiddeling te kennen dan koppels die zich nooit bevinden in deze situatie (goede communicatie). Personen met een matige communicatie schatten, gegeven dat de mogelijkheden om samen te communiceren nog toereikend zijn, mogelijk hun eigen slaagkansen van de bemiddeling nog voldoende hoog in. Als er daarentegen sprake is van een slechte communicatie waarin er meer dan maandelijks niet meer gecommuniceerd wordt, zien we echter geen significant verband. De graad van conflict na de beslissing om definitief uit elkaar te gaan is niet bepalend voor het al dan niet kennen van professionele echtscheidingsbemiddeling.

Wat de redenen van echtscheiding betreft is enkel de reden "relationele problemen" relevant om het kennen van bemiddeling te verklaren. De kans dat koppels die als echtscheidingsreden relationele problemen opgeven op de 
hoogte zijn van professionele echtscheidingsbemiddeling is 1,361 keer diezelfde kans bij koppels met andere echtscheidingsredenen.

Door de wetswijziging van juli 2006 werden rechters verplicht ouders met minderjarige kinderen te informeren over de mogelijkheid tot professionele echtscheidingsbemiddeling. In model 2 zien we echter geen globaal effect van deze wetswijziging op het kennen van bemiddeling. Wanneer we echter model 3 voor scheidingscohorte 2001-2006 vergelijken met model 4 voor scheidingscohort 2006-2010 zien we echter na de wetswijziging een ander patroon inzake de factoren. Na de wetswijziging zijn expartners met kinderen duidelijk meer op de hoogte van bemiddeling dan ex-partners zonder kinderen en dit onderscheid was er niet voor de scheidingscohorte van 2001-2006. Tevens zullen ex-partners die scheiden omwille van problemen met betrekking tot de kinderen beter op de hoogte zijn van professionele echtscheidingsbemiddeling. Dit toont duidelijk aan dat de wetswijziging zijn effect niet gemist heeft en dat men door deze beleidsmaatregel erin geslaagd is de doelgroep die men voor ogen had beter te informeren.

De selectiviteit in het kennen van professionele echtscheidingsbemiddeling vaagt echter in tegenstelling tot wat verwacht zou worden in een later stadium van integratie van de innovatie niet uit. De parameters die de samenhang tussen het opleidingsniveau en de kennis van bemiddeling meten worden zelfs groter maar een interactie-effect tussen opleidingsniveau en cohorte laat geen significante wijziging over de tijd zien. Dit betekent dat de kloof tussen de kennis van laagopgeleiden en die van hoog opgeleiden in strijd met de hypothese zeker niet kleiner is geworden. De hypothese dat kennis over professionele echtscheidingsbemiddeling meer aselect in de populatie verspreid raakt na de wetswijziging wordt wel bevestigd door drie andere factoren. Zo is het hebben van een gemeenschappelijke eigendom, een hogere mate van conflict en het hebben van relationele problemen niet langer significant voor de scheidingscohorte van na 2006.

De verklaringskracht van de kenmerken die we als mogelijke invloedrijke factoren selecteerden, verhoogt. Model 3 waarin de respondenten gescheiden voor 2006 opgenomen zijn (cohorte 1) heeft een verklaringskracht van $10,8 \%$, terwijl dezelfde variabelen $15,5 \%$ van de variantie verklaren voor de tweede cohorte (model 4).

\subsection{WIE GEBRUIKT PROFESSIONELE ECHTSCHEIDINGSBEMIDDELING?}

Een vijfde $(20,5 \%)$ van de 1.152 respondenten die professionele echtscheidingsbemiddeling kennen, maken er ook gebruik van. Tabel 2 geeft voor alle kenmerken uit tabel 1 weer of ze bepalend zijn inzake het gebruik van professionele echtscheidingsbemiddeling, maar ook enkele andere kenmerken worden opgenomen in deze modellen. Overeenkomstig tabel 1 presenteren we eerst twee geaggregeerde modellen over cohorten heen waarin we cohorte niet (model 5) en daarna wel (model 6) opnemen als verklarende variabele. Model 7 en 8 zijn verklaringsmodellen apart voor de gescheidenen van voor respectievelijk na de wet van 2006. Aangezien het aantal geobserveerde observaties voor model 8 beperkt is ( $N=244$ ) bespreken we eveneens de parameters die significant zijn op niveau $\alpha=0,1$.

Model 5 toont aan dat als de vrouw een diploma voortgezet onderwijs heeft, het ex-koppel meer kiest voor professionele echtscheidingsbemiddeling. 
Tabel 2 Logistische regressie voor kennis over professionele echtscheidingsbemiddeling (oddsratio's)

Model $5 \quad$ Model $6 \quad$ Model 7 Model 8

\begin{tabular}{|c|c|c|c|c|c|}
\hline \multirow[t]{2}{*}{ ACHTERGRONDKENMERKEN } & Geslacht (vrouw) & 1,104 & 1,106 & 1,275 & 0,619 \\
\hline & Leeftijd bij scheiding & 1,010 & 1,009 & 1,010 & 1,003 \\
\hline COHORT & Cohort (na) & & 1,092 & & \\
\hline SOCIAAL - ECONOMISCHE & Opleiding man (hoger sec) & 0,904 & 0,903 & 0,968 & 0,881 \\
\hline \multirow[t]{4}{*}{ KENMERKEN } & Opleiding man (voortgezet) & 1,225 & 1,228 & 1,377 & 1,135 \\
\hline & Opleiding vrouw (hoger sec) & 1,185 & 1,180 & 1,305 & 1,121 \\
\hline & Opleiding vrouw (voortgezet) & $1,801 *$ & $1,791 *$ & 1,732 & 2,368 \\
\hline & Activiteit (actief) & 0,778 & 0,777 & 0,760 & 0,828 \\
\hline RELATIEKENMERKEN VOOR & Geluk & 0,924 & 0,923 & 0,941 & 0,857 \\
\hline SCHEIDING & Ouderlijke scheiding (ja) & 1,202 & 1,198 & 1,241 & 1,078 \\
\hline \multirow[t]{2}{*}{ GEZINSKENMERKEN } & Kinderen & 1,348 & 1,342 & 1,113 & 5,483 \\
\hline & Eigenaar (Gemeenschappelijk) & 1,101 & 1,096 & 1,112 & 1,083 \\
\hline RELATIEKENMERKEN NA & Communicatie (matig) & 1,047 & 1,044 & 0,945 & 1,516 \\
\hline \multirow[t]{4}{*}{ SCHEIDING } & Communicatie (slecht) & 1,032 & 1,027 & 0,895 & 1,573 \\
\hline & Conflict & 1,035 & 1,036 & $1,058^{*}$ & 0,961 \\
\hline & Initiatief (man) & 1,502 & 1,501 & 1,628 & 1,404 \\
\hline & Initiatief (vrouw) & 1,487 & 1,487 & 1,366 & 2,556 \\
\hline \multirow[t]{5}{*}{ ECHTSCHEIDINGSREDENEN } & Relatieproblemen & 0,804 & 0,808 & 0,985 & $0,441 *$ \\
\hline & Gedragsproblemen & 0,689 & 0,689 & 0,669 & 0,942 \\
\hline & Economische problemen & 1,011 & 1,010 & 0,999 & 0,993 \\
\hline & Ontrouw & 0,983 & 0,988 & 0,963 & 1,098 \\
\hline & Problemen met kinderen & 1,269 & 1,266 & 0,952 & $2,687^{*}$ \\
\hline Pseudo $\mathbf{R}^{2}$ & & 0,06 & 0,06 & 0,06 & 0,15 \\
\hline $\mathbf{N}$ & & 1068 & 1068 & 824 & 244 \\
\hline
\end{tabular}

Bron: Scheiding in Vlaanderen, 2009-2010 
De relatiekenmerken voor scheiding blijken opnieuw geen significante rol te spelen in de keuze om bemiddeling te volgen. Het speelt geen rol in de keuze tot bemiddeling of de ouders van de respondent gescheiden zijn of niet. Het ervaren van een ouderlijke scheiding leidt niet tot een hogere kans om bemiddeling te kennen of te gebruiken. De persoonlijke ervaring van de respondent met een ouderlijke scheiding en de daaraan gekoppelde nadelen ondervinden, hebben dus blijkbaar geen invloed op de keuze voor professionele echtscheidingsbemiddeling. Dit laatste blijft het geval als de leeftijd van de respondent bij ouderlijke echtscheiding mee in rekening wordt gebracht. Er zou immers vermoed kunnen worden dat de impact van de ouderlijke echtscheiding op kinderen groter is als deze nog thuis wonen. Echter, een bijkomende analyse toont aan dat een echtscheiding die plaatsvond voor de leeftijd van 18 jaar nadien geen effect op de keuze om professionele echtscheidingsbemiddeling aan te wenden in de eigen echtscheidingsprocedure. Te weinig ouders scheidden na de wet van 2001 waardoor het intergenerationeel effect van ouders die ook reeds bemiddeling gebruikten niet door de data getest kon worden. Ook het gerapporteerde geluksgevoel in de huwelijksrelatie het jaar voor de scheiding maakt geen verschil uit als we het gebruik van professionele echtscheidingsbemiddeling willen verklaren.

De gezinskenmerken hebben geen enkele invloed hebben op het gebruik van professionele echtscheidingsbemiddeling. Het hebben van kinderen is in de geaggregeerde modellen waarin vooral de vroegste scheidingscohort vertegenwoordigd is, geen stimulans voor het ex-koppel om voor professionele echtscheidingsbemiddeling te kiezen. Ook het hebben van een woning in gemeenschappelijke eigendom is geen reden om sneller of minder snel te kiezen voor bemiddeling.

Volgens de redenering dat de kans op het bekomen van de voor- en nadelen van professionele echtscheidingsbemiddeling verschilt tussen ex-koppels werden ook relationele omgangskenmerken opgenomen. Bij de beslissing tot het gebruiken van bemiddeling zijn ex-koppels echter niet beïnvloed door de mate van conflict noch door de kwaliteit van de communicatie binnen hun relatie noch door het geslacht van de initiatiefnemer.

Alle ex-koppels maken evenveel kans om voor bemiddeling te kiezen, onafhankelijk van de opgegeven emotionele echtscheidingsreden. Zij houden geen rekening met mogelijke slaagkansen of daaraan gekoppelde voor- of nadelen.

Uit model 6 blijkt dat evenmin als de kennis het gebruik van professionele echtscheidingsbemiddeling niet gestegen is door de invoering van de wet van 2006 . Wel zien we in de steekproef gebruikt in model 8 overeenkomstig een doorgedreven verspreiding van de kennis over professionele echtscheidingsbemiddeling bij ouders, ook een verhoogd gebruik in de scheidingsohorte 2006-2010. Ouders hebben vijf keer $(5,483)$ meer kans om in bemiddeling te gaan ten opzichte van ex-koppels zonder kinderen. Koppels die 'problemen met kinderen' als één van de drie redenen van scheiding opgeven, hebben eveneens meer kans $(2,556)$ om in bemiddeling te gaan dan koppels die andere redenen opgeven. Dit bevestigt op steekproefniveau niet alleen dat er een betere informatieverstrekking is van de rechter, maar ook dat ouders hier effectief gevolg aan geven. Deze resultaten moeten echter met enige voorzichtigheid gegeneraliseerd worden. Door de kleine 
steekproef zijn deze parameters slechts lager dan .1 maar bereiken ze niet het vereiste significantieniveau van .05 om het ook als een populatieresultaat te mogen beschouwen.

Op basis van de innovatietheorie vermoedden we een verzwakking van de oorspronkelijke effecten door de betere integratie van bemiddeling als innovatie in de echtscheidingsprocedure. Het opleidingsniveau van de vrouw bleek een belangrijke determinant om het gebruik van professionele echtscheidingsbemiddeling te verklaren. Voor de gescheiden personen na 2006 is het effect van hoger opgeleid te zijn voor vrouwen niet meer significant maar de geschatte kans blijft wel aanzienlijk hoger dan dezelfde kans voor laag opgeleide vrouwen gegeven een oddsratio van 2,368. Gegeven de kleine steekproefomvang in de laatste cohorte moet het uitblijven van de significantie in model 8 opnieuw met enige omzichtigheid bekeken worden en kunnen we niet helemaal stellen dat bemiddeling recenter door een minder aselecte groep op vlak van opleiding gebruikt wordt. Verder zien we in de scheidingscohorte van 2006 tot 2010 dat het initiatief van de vrouw tot de scheiding het gebruik van bemiddeling bevordert. Tot slot stellen we vast dat voor deze laatste cohorte het rapporteren van relatieproblemen als reden voor de scheiding de kans om bemiddeling te gebruiken verkleint. Mogelijk wordt de slaagkans van de bemiddeling lager ingeschat indien de relationele problemen voordien te hoog oplopen.

Model 6 verklaart 5,8\% van de variantie. De gekozen variabalen kunnen met andere woorden slechter verklaren waarom (ex-)koppels kiezen voor bemiddeling dan dat zij de kennis over bemiddeling verklaren. Toch zien we dat verklaringskracht van het model verhoogt voor opeenvolgende cohorten. Model 7 heeft voor cohorte 1 een verklaringskracht van $6,0 \%$, terwijl model 8 voor de tweede cohorte $15,6 \%$ van de variantie verklaart.

\section{Conclusies En AANBEVElingen}

In deze bijdrage bestudeerden we op basis van gegevens uit "Scheiding in Vlaanderen" de mate waarin ex-partners gescheiden na februari 2001 professionele echtscheidingsbemiddeling kennen en er vervolgens ook gebruik van maken. Bijzondere aandacht ging hierbij uit naar de beleidsbeslissingen doorheen de tijd. Met name het effect van de wet van 2006 die de rechter verplicht ex-partners met kinderen te informeren over professionele echtscheidingsbemiddeling, werd als ankerpunt gebruikt om twee opeenvolgende scheidingscohorten te onderscheiden. Vanuit de innovatietheorie veronderstelden we dat de kennis over en het gebruik van bemiddeling meer verspreid zou geraken doorheen de tijd en dat de selectiviteit van de groep die bemiddeling kent en/of gebruikt zou afnemen.

De resultaten omtrent de kennis over professionele echtscheidingsbemiddeling tonen vooreerst aan dat de kans om bemiddeling te kennen niet voor iedereen dezelfde is. Des te hoger men opgeleid is des te meer kans men heeft om geïnformeerd te zijn over professionele echtscheidingsbemiddeling. Veder hebben ex-partners die relationele problemen als reden van de scheiding opgeven meer kans om professionele bemiddeling te kennen. Mogelijk wordt professionele echtscheidingsbemiddeling sneller in verband gebracht met relationele problemen dan met andere problemen die de reden van echtscheiding kunnen zijn waardoor deze personen sneller kennis verwerven hierover. Ook ex-partners met een gemeenschappelijke woning zijn meer geneigd professionele echtscheidingsbemiddeling te kennen. In lijn 
met de innovatietheorie (Rogers, 2003) en het gezondheidsgedragmodel (Andersen, 1995) veronderstellen we dat voornamelijk personen die meer noodzaak voelen of een groter voordeel kunnen halen uit een innovatie als bemiddeling, ook beter op de hoogte zijn ervan. Ook ex-partners die een matige kwaliteit van communicatie rapporteren kennen professionele echtscheidingsbemiddeling vaker dan zij die goed of slecht communiceren. Mogelijk schatten ze zowel het nut als de slaagkans van de bemiddeling nog voldoende hoog in waardoor zich informeren toch de moeite waard is. Zoals in de hypothesen vermeld speelt de subjectief ingeschatte slaagkans hier mogelijk een rol en zullen koppels zich niet meer informeren als ze de slaagkans van bemiddeling te laag inschatten gegeven hun slechte communicatie. Eveneens zullen koppels die hun communicatie als goed beschouwen, minder nood voelen om zich te informeren over bemiddeling.

De wet van 18 juli 2006 heeft niet geleid tot meer kennisverspreiding over professionele echtscheidingsbemiddeling. Wel hebben expartners met kinderen in de latere scheidingscohorte systematisch meer kans om geïnformeerd te zijn. Het doel van het beleid om een bijzonder kwetsbare groep beter te informeren over bemiddeling lijkt dus bereikt door de verplichte informatieverstrekking door de rechter t.a.v. ex-partners met kinderen. Toch is de groep die kennis heeft over professionele echtscheidingsbemiddeling nog steeds een selecte groep. Uit de vergelijking van de cohorten gescheiden voor en na de wetswijziging van 18 juli 2006 blijkt immers dat de oorspronkelijke kenniskloof tussen laag- en hoogopgeleiden niet verkleind is over de tijd. Volgens de innovatietheorie kunnen we dan ook concluderen dat deze innovatie nog in een vroege fase van integratie zit en dat het nog even zal duren (afhankelijk van onder andere beleidsingrijpen) vooraleer dit gekend en gebruikt wordt doorheen alle lagen van de bevolking.

Een analyse over het gebruik van bemiddeling laat zien dat dit gebruik verschillend is naargelang het opleidingsniveau van de betrokkenen, met name ex-partners waarvan de vrouw hoger opgeleid is maken meer gebruik van bemiddeling. Er is geen zelfde effect bij de opleiding van de man. Dit is mogelijk te verklaren vanuit de traditionele genderrolverdeling. Sommige onderzoekers gingen ervan uit dat de onevenwichtige relatie tussen man en vrouw betekende dat de vrouw meer gebaat was met een echtscheidingsprocedure gevoerd via een rechter waarbij de rechten van de vrouw beter beschermd konden worden (Bryan, 1992). Een hogere educatiegraad bevorderde echter voor vrouwen niet alleen de economische onafhankelijkheid maar ook de psychologische onafhankelijkheid (Kalmijn \& Poortman, 2006). Dit zou de verhoogde kans op het gebruik van bemiddeling voor deze groep t.o.v. de vrouwen die lager opgeleid zijn kunnen verklaren. Doordat hoger opgeleid zijn vooral een emancipatorisch effect heeft t.a.v. vrouwen, zien we niet hetzelfde effect optreden bij de man. Wel zijn de verschillen naar opleidingsniveau wat het gebruiken van professionele echtscheidingsbemiddeling betreft kleiner dan wat de verschillen inzake kennis betreft.

Na de wetswijziging van juli 2006 waarbij rechters verplicht worden ouders te informeren over professionele echtscheidingsbemiddeling zien we geen algemene toename van het gebruik van bemiddeling, wel is er in de steekproef een duidelijk gunstig effect voor koppels met kinderen. De ondervraagde respondenten zijn sindsdien niet alleen beter op de hoogte maar maken ook effectief meer gebruik van 
professionele echtscheidingsbemiddeling. De wetswijziging van 2006 die als doel had bemiddeling te promoten bij ouders die willen scheiden, tendeert volgens deze steekproefgegevens gunstig gevolg te krijgen. Een meer uitgebreide onderzoekspopulatie in toekomstig onderzoek zal uitmaken of deze trend volledig veralgemeenbaar is.

Een belangrijk hiaat bij het bestuderen van de kennis over en het gebruik van bemiddeling is het ontbreken van inkomen als verklarende variabele. Aangezien we enkel informatie hadden over het huidige inkomen en niet over het inkomen op moment van scheiding, opteerden we ervoor deze variabele niet op te nemen. Waarschijnlijk missen we hier een belangrijke factor die de variatie in het gebruik van bemiddeling kan verklaren. $\mathrm{Er}$ is immers reeds een positief verband aangetoond tussen inkomen en het gebruik van bemiddeling (Daniëls \& Buysse, 2010). Mogelijk kunnen inkomensverschillen ook inzicht brengen in de variatie wat betreft het kennen van professionele echtscheidingsbemiddeling. Een vergelijking van de verklaringskracht van de modellen over kennen en gebruiken doet echter vermoeden dat we vooral op vlak van gebruik nog meer bijkomende factoren moeten veronderstellen.

We kozen ervoor de data te bestuderen vertrekkend vanuit twee conceptuele kaders, met name het innovatiemodel van Rogers (2003) en het gezondheidsgedragmodel van Andersen (1995). In de toepassing van beide theorieën zien we gegeven de context van professionele echtscheidingsbemiddeling enige overlap maar ook nuttige verschillen. Rogers (2003) spreekt van risico en risicotolerantie waardoor een innovatie al dan niet aanslaat gegeven individuele kenmerken van de toekomstige gebruiker die een kosten-batenanalyse maakt alvorens zich de innovatie eigen te maken. Een gedifferentieerde perceptie van het risico, alsook een variërende risicotolerantie voor verschillende groepen, zijn het resultaat van individuele kenmerken. Wanneer we de innovatie invullen in termen van een professioneel zorgaanbod, spoort zijn visie met die van Andersen (1995) die in zijn eerste versie van de gezondheidsgedragtheorie eveneens van individuele kenmerken vertrekt die ertoe leiden of men al dan niet gebruik maakt van zorg.

De bijkomende verdienste van de innovatietheorie schuilt in het opnemen van de tijdsdimensie als vigerende factor. Het diffusiemechanisme maakt dat een nieuwigheid almaar meer mensen bereikt doordat informatie meer verspreid geraakt en hierdoor risico's minstens beter gekend zijn. Andersen (1995) daarentegen maakt zijn theorie sterk door de ruimere context te betrekken in latere versies van zijn model. Niet alleen de individuele kenmerken maar ook de kenmerken van de dienstverlening zelf alsook het ruimere beleid, bepalen of individuen overgaan tot medische consumptie en hieraan een tevreden gevoel overhouden. Onnodig te vermelden dat dergelijk denkkader ook ingevuld kan worden voor een niet-medisch zorgaanbod zoals professionele echtscheidingsbemiddeling. Beide theorieën laten toe de kennis over en het gebruik van professionele echtscheidingsbemiddeling te duiden.

De data van "Scheiding in Vlaanderen" lieten toe een tijdsdimensie op te nemen in de analyses. De beperkingen van de data sloten echter aandacht voor de context waarbinnen professionele echtscheidingsbemiddeling tot stand komt uit bij de analyses. Echter, bij het formuleren van enkele beleidsaanbevelingen in het licht van de empirische resultaten, willen we ook aandacht hebben voor de specifieke maatschappelijke context. 
Deze resultaten over kennen van bemiddeling laten duidelijk zien dat de wet van 2006 een gunstig effect had voor een specifieke doelgroep. Ex-partners met kinderen zijn in de recente scheidingscohorte duidelijk meer geïnformeerd over professionele echtscheidingsbemiddeling. De uitdaging die voor ligt betreft het algemeen verspreiden van informatie over dit type van echtscheidingszorg. Indien mensen goed geïnformeerd zijn over de kenmerken van de dienstverlening die echtscheidingsbemiddelaars aanbieden om een echtscheidingsprocedure zo gunstig mogelijk te laten verlopen, kunnen ze vervolgens een adequate keuze maken over het al dan niet ingaan op dit aanbod van de bemiddelaars. Een proactief informatiebeleid is hierbij noodzakelijk. Informeren via de rechter blijkt effectief. Het verdient dus aanbeveling om deze informatieplicht voor rechters te veralgemenen naar alle personen die een echtscheidingsaanvraag indienen, ongeacht of er kinderen zijn of niet.

Vervolgens moeten de informatiebronnen die mensen kunnen raadplegen over professionele echtscheidingsbemiddeling voldoende helder zijn opdat de kosten-batenanalyse m.b.t. deze dienstverlening door het grote publiek zo accuraat mogelijk wordt gemaakt. De 5B's van Vandersteene (2007) kunnen een leidraad vormen om de beschikbare informatie te evalueren op zijn effectiviteit. Mensen informeren moet immers als doel hebben duidelijkheid scheppen omtrent hoe bereikbaar, beschikbaar, begrijpbaar, bruikbaar en betaalbaar professionele echtscheidingsbemiddeling als vorm van dienstverlening in de echtscheidingsprocedure is voor iemand.

Wat het promoten van het gebruik betreft zijn we eerder conservatief. Aangezien bemiddeling heden betalend is, kan niemand verplicht worden om van deze dienstverlening gebruik te maken. Wel kan een doorgedreven toegankelijkheidsbeleid waarbij in het kader van preventie de kosten van een kennismaking met bemiddeling door de gemeenschap gedragen worden, of professionele echtscheidingsbemiddelaars aangespoord worden om tegen een gunstig tarief een eerste kennismakingssessie te voorzien, overwogen worden.

Zeker vermeldenswaardig is het belang van kwaliteitsbewaking van het zorgaanbod. Hiervoor is het cruciaal dat zelfstandig professionele bemiddelaars en de hen overkoepelende instanties voortdurend de vinger aan de pols houden en de kwaliteit met inbegrip van de toegankelijkheid van hun dienstverlening voortdurend zelf evalueren en bijsturen indien nodig. Kwaliteitsvolle opleidingscentra die basisopleidingen en navorming bieden voor professionele echtscheidingsbemiddelaars waarbij het zorgaanbod afstemmen op (sociaal-economische) maat van de cliënt een van de prioriteiten is, zijn essentieel.

Naast de professionele echtscheidingsbemiddelaars die als zelfstandig hulpverleners koppels in scheiding begeleiden is het belangrijk ook te verwijzen naar het hulpaanbod inzake scheiding binnen de reguliere welzijnssector. Verscheidene Centra voor Algemeen Welzijn kozen recent ervoor om lokaal een geïntegreerd aanbod te ontwikkelen rond scheiding. Het visiedossier "Steun in het traject. Eerstelijnshulp bij scheiding" van Steunpunt Algemeen Welzijnswerk (SAW, 2013) is gebaseerd op de werking van 4 CAW's (CAW Delta, CAW Sonar, CAW De Kempen, CAW Mozaïek), aangevuld met een reflectie van de medewerkers van de Gentse bezoekruimte Half-Rond (CAW Visserij). In deze tekst bevestigen de auteurs onze bevinding dat het vooral de sociaal-economisch sterkere groepen zijn die gebruik maken van echtscheidingshulpverlening. "De 
CAW's bereiken met hun specifiek scheidingsaanbod doorgaans een hogere socio-economische bevolkingslaag dan in hun ander aanbod." ." (Visietekst SAW, p. 16). Verder benadrukken zij het belang van een goed doordacht traject. "In de beginfase staat 'trajectbemiddeling' (Melis en Jacobs, 2009) centraal: mensen worden geholpen om te beslissen via welke weg ze hun meningsverschil zullen oplossen. Eenmaal beide partners gekozen hebben om uit elkaar te gaan, wordt er met hen een gesprek opgezet over het oplossingskader. Dit is trajectbemiddeling: welke weg gaan ze nemen om hun geschil aan te pakken?, zullen ze zelf onderhandelen en regelen of zullen ze de regeling overlaten aan een derde?, wie zal die derde dan zijn: een advocaat, een notaris, een rechter of een scheidingsbemiddelaar? (...) De 'trajectbemiddeling' is het actief begeleiden van de keuze voor een bepaald traject in de afhandeling van de scheiding en vereist specifieke competenties van de hulpverlener, zowel op juridisch vlak als op vlak van het kunnen toewerken naar een gedragen beslissing." (Visietekst SAW, p. 31).

Analoog aan de uitbreiding die de theorie van Andersen (1995) onderging, durven we in navolging van de visietekst van SAW (2013) veronderstellen dat het ook de effectiviteit van professionele echtscheidingsbemiddeling ten goede komt, eerder dan enkel rekening te houden met individuele kenmerken van de cliënten, deze vorm van hulpverlening verder te ontplooien richting het ruimere denkkader van een volledig geïntegreerd aanbod inzake scheidingszorg waar een veelheid aan organisaties die een betekenisvolle rol met het oog op een weloverwogen en succesvol echtscheidingstraject kunnen spelen, krachten bundelen en op elkaar afstemmen en inspelen.
Hiermee sluiten we eveneens aan bij een van de gunstige kenmerken die Rogers (2003) vooropstelt opdat een innovatie sneller ingang vindt, nl. het compatibel zijn met bestaande praktijken en waarden. Door bemiddeling als een van de mogelijke pistes te zien in een waaier van keuzemogelijkheden om te komen tot een bevredigend echtscheidingstraject voor alle betrokkenen, komen we tegemoet aan deze gunstige vereiste van compatibiliteit. Vervolgens past de suggestie om een eerste kennismakingssessie gratis of tegen voordelig tarief aan te bieden in wat hij de testbaarheid van een innovatie noemt. Indien deze kennismaking met professionele echtscheidingsbemiddeling bovendien structureel ingebed wordt in het echtscheidingstraject, wordt het voor de betrokkenen ook eenvoudiger om deze innovatie effectief te kennen en te gebruiken. Tot slot kan professionele echtscheidingsbemiddeling ook gebaat zijn met bijkomend onderzoek naar langetermijneffecten. Immers, wanneer meetbare en zichtbare positieve resultaten ook op populatieniveau kunnen toegeschreven worden aan deze vorm van echtscheidingshulp en deze eventueel gunstige effecten gerapporteerd worden in de media, zullen personen betrokken bij echtscheiding mogelijk ook sneller de relatieve voordelen ervan inzien en zal het gebruik van echtscheidingsbemiddeling meer algemeen verspreid raken. 


\section{REFERENTIES}

Addis, M. E. \& Mahalik, J. R. (2003). Men, masculinity, and the contexts of help seeking. American Psychologist, 58, 5-14.

Adsei (2012) Evolutie van het aantal echtscheidingen per gewest, 1990 - 2012. Algemene Directie Statistiek en Economische Informatie - Thematische Directie Samenleving.

Alonso, J. (2004). Use of mental health services in Europe. Results from the European Study of Epidemiology of Mental Disorders (ESEMeD) Project. Acta Psychiatrica Scandinavica, 110, 35.

Andersen, R. M. (1995). Revisiting the behavioral model and acces to medical care: does it mather? Journal of health and social behavior, 1-10.

Bastaits, K., Van Peer, C., Alofs, A., Pasteels, I., \& Mortelmans, D. (2011). Hoe verloopt een echtscheiding in Vlaanderen. In D. Mortelmans, I. Pasteels, P. Bracke, K. Matthijs, J. Van Bavel, \& C. Van Peer, Scheiding in Vlaanderen (85 - 112). Leuven: Acco.

Bongers I., J. Van Der Meer, J. Van Den Bos en J. Mackenbach, (1997), "Socio-economic differences in General Practitioner and
Outpatient specialist care in the Netherlands: a matter of health insurance", Social Science and Medicine, 44, 1161-1168.

Buysse, A. (2011). Bijdrage op het IPOSEindcongres 'Scheiden anders bekeken'. 30.09. 2011.

Bryan, P. E. (1992). Killing us softly: Divorce mediation and the politics of power. Buffalo law review , 40(2), 441-523.

Cohen, O., Luxenburg, A., Dattner, N., \& Matz, D. E. (2000). Suitability of divorcing couples for mediation: A suggested typology. American journal of familiy therapy, 27(4), 329-344.

Colman, E., Symoens, S. \& Bracke, P. (2011) Zorggebruik. In D. Mortelmans, I. Pasteels, P. Bracke, K. Matthijs, J. Van Bavel, \& C. Van Peer, Scheiding in Vlaanderen (pp. 267-281). Leuven: Acco.

Corijn, M. (2005). Huwen, uit de echtscheiden en hertrouwen in België en in het Vlaamse gewest. CBGS Werkdocumenten, 2005(5), 98.

Corijn, M., \& Lodewijckx, E. (2009/4). Echtscheiding en leefvorm na echtscheiding in het Vlaamse Gewest: verschillen naar herkomst. Studiedienst van de Vlaamse regering . 
Corijn, M., Pasteels, I. \& Mortelmans, D. (2012) Gescheiden ouders, gescheiden kinderen? Scheiding in Vlaanderen: korte beleidspaper.

Daniëls, L., \& Buysse, A. (2010). Echtscheiding: (Echt)scheidingsbemiddeling. Mechelen: Kluwer.

Daniëls, L., Taelman, P., \& Buysse, A. (2010). Bemiddeling. Rechtskroniek voor het notariaat (16), 1-27.

Daniëls, L., Taelman, P., \& Buysse, A. (2010). Doen mensen tijdens hun scheiding beroep op een bemiddelaar? IPOS , 1.

De Graaf, P. M., \& Kalmijn, M. (2006). Change and stability in the social determinants of divorce: A comparison of mariage cohorts in the Nederlands. Oxfort University Press , 561-572.

De Graaf, P. M., \& Kalmijn, M. (2006). Divorce motives in a period of rising divorce: Evidence drom a Dutch life-history survey. Journal of family issues , 27(4), 483-505.

De Graeve D. en I. Duchesne, (1997), Equity in health and in medical care consumption in Belgium, report 97/341, Antwerp: SESO.

De Prins L., W. Peersman en J. De Maeseneer, (1998), "Lager opgeleid, meer naar de huisarts?", Huisarts en Wetenschap, 41, 173-178.
Ellis, D., \& Stuckless, N. (1996). Mediating and negotiating marital conflicts. Calif.: Sage: Thousand Oaks.

Emery, R. E. (1995). Divorce mediation: Negotiating agreements and renegotiating relationships. Family relations, 44(4), 377383.

Gonzalez, J. M., Alegria, M., Prihoda, T. J., Copeland, L. A., \& Zeber, J. E. (2011). How the relationship of attitudes toward mental health treatment and service use differs by age, gender, ethnicity/race and education. Social Psychiatry and Psychiatric Epidemiology, 46, 45-57.

Goode, W. J. (1951). Economic factors and marital stability. American Sociological review , 16, 802-812.

Goode, W. J. (1962). Marital satisfaction and instability: A cross-cultural class analysis of divorce rates. International social science journal , 14, 507-526.

Gouwy, A., Christiaens, W., \& Bracke, P. (2008). Mental health service use in the general Belgian population: estimating the impact of mental health and social determinants. Arch Public Health, 66, 50-68.

Hoffmann, V. (ed.)( 2011):Knowledge and Innovation Management. Module Reader. Hohenheim University. 
Kalmijn, M. \& Poortman, A.-R. (2006). His or her divorce? The gendered nature of divorce and its determinants. European Sociological review , 201-214.

Kelly, J. B. (1996). A decade of devorce mediation research. Family and conciliation courts review , $373-385$.

Kelly, J. B. (2004). Family mediation research: Is there empirical support for the field? Conflict resolution quarterly, 22(1-2), 3-35.

Kelly, J. B. (1993). Developing and implementing post-divorce parenting plans: Does the forum make a difference? In C. Depner, J. Bray, e.a., Non-residential parenting: New vistas in family living. Calif.: Thousand Oaks.

Kouzis, A. C. \& Eaton, W. W. (1998). Absence of social networks, social support and health services utilization. Psychological Medicine, 28, 1301-1310.

Lowenstein, L. F. (2009). Mediation with separated parents: recent research. Journal of divorce \& remarriage, 50(4), 233-247.

Markey, C. N., Markey, P. M., Schneider, C., \& Brownlee, S. (2005). Marital status and health beliefs: Different relations for men and women. Sex Roles, 53, 443-451.

Melis, B. \& Jacobs, M. (2009) 'Werkstuk PAV Bemiddeling'. Academiejaar 2008-2009.
Mirowsky, J., \& Ross, C. E. (1998). Education, personal control, lifestyle and health: a human capital hypothesis. Research on aging, 415-449.

Mortelmans, D., Pasteels, I., Bracke, P., Matthijs, K., Van Bavel, J., \& Van Peer, C. (2011). Scheiding in Vlaanderen. Leuven: Acco.

Pasteels, I., Mortelmans, D., \& Van Bavel, J. (2011). Steekproef en dataverzameling. In D. Mortelmans, I. Pasteels, P. Bracke, K. Matthijs, J. Van Bavel, \& C. Van Peer, Scheiding in Vlaanderen (pp. 27-64). Leuven: Acco.

Pearson, J., \& Thoennes, N. (1988). Supporting children after divorce: the influence of custody on child support levels and payments. Family law quarterly , 319-339.

Przybyla-Basista, H. (2008) The influence of spouses resistance on their decision to enter into divorce mediation. Journal of divorce \& remarriage, 48(3-4), 67-89.

Robinson, L. (2012) Changeology. How to enable groups, communities and societies to do things they've never done before. 272p.

Rogers, E. M.(1962) Diffusion of Innovations. The Free Press of Glencoe, New York. $367 p$. 
Rogers, E. M., Shoemaker, F.(1971) Communication of Innovations. A Cross-Cultural Approach. Second Edition. The Free Press, New York. 476 pp.

Rogers, E. M. (1983) Diffusion of Innovations. Third Edition. The Free Press of Glencoe, New York. 453 pp.

Rogers, E. M. (1995) Diffusion of Innovations. Fourth Edition. The Free Press of Glencoe, New York. 518 pp.

Rogers, E. M.. (2003) Diffusion of Innovations. Fifth Edition. The Free Press of Glencoe, New York. 550 pp.

Steunpunt Algemeen Welzijnswerk (2013) Visiedossier "Steun in het traject. Eerstelijnshulp bij scheiding". Werkdocument overleg september 2013.

Tishler, C. L., Landry-Meyer, L., \& Bartholomae, S. (2003). Mediation and child support. Journal of divorce \& remarriage, 38(3), 129-145.

Umberson, D. (1987). Family Status and Health Behaviors - Social-Control As A Dimension of Social Integration. Journal of Health and Social Behavior, 28, 306-319.

Van Peer, C., Bastaits, K., \& Mortelmans, D. (2011/9). De impact van de echtscheidingswetgeving op het verloop van een echtscheiding in Vlaanderen. Brussel: Studiedienst van de Vlaamse regering.

Vandamme, R., \& Evers, D. (2008). Bemiddeling voor iedereen. Leuven: mediation instituut Vlaanderen.

Vander Steene, A. (2007). Vroegtijdige eerstelijnshulpverlening in scheidingssituatie voorkomt vechtscheidingen. Tijdschrift voor welzijnswerk , 21(283), 81-91.

Van der Heyden JH, Demarest S, Tafforeau J, Van Oyen H. (2003) Socio-economic differences in the utilisation of health services in Belgium. Health Policy; 65:153-65.

Van Der Meer J., J. Van Den Bos en J. Mackenbach, (1996), "Socioeconomic differences in utilization of health services in a Dutch population: the contribution of health status", Health Policy, 37, 1-18.

Van Doorslaer E, Masseria C, Koolman X. (2006) Inequalities in access to medical care by income in developed countries. CMAJ; $174: 177-83$.

Vasiliadis, H. M., Tempier, R., Lesage, A., \& Kates, N. (2009). General Practice and Mental Health Care: Determinants of Outpatient Service Use. Canadian Journal of Psychiatry-Revue Canadienne de Psychiatrie, 54, 468-475. 
2014, Vol $4-\mathrm{Nr} 4$

Vollebergh, W., De Graaf, R., Schoemakers, C., Ten Have, M., van Dorsselaer, S., Spijker, J. et al. (2003). Zorggebruik en zorgbehoefte. In Psychiatrische stoornissen in Nederland (pp. 61-70). Utrecht: TrimbosInstituur.

Walton, L., Oliver, C., \& Griffin, C. (1999). Divorce mediation: The impact of mediation on the psychological well-being of children and parents. Journal of community \& applied social psychology, 9, 35-46.

Wejnert, B. (2002). Integrating models of diffusion of innovations: A conceptual framework. Annual review of sociology , 297.

Wet. (19 februari 2001). Wet inzake de proceduregebonden bemiddeling in familiezaken.

Wet. (18 juli 2006). Wet tot het bevoorrechten van een gelijkmatig verdeelde huisvesting van het kind van wie de ouders gescheiden zijn en tot regeling van de gedwongen tenuitvoerlegging inzake huisvesting van het kind.

Wet. (21 februari 2005). Wet tot wijziging van het gerechtelijk wetboek in verband met de bemiddeling.

Wetsvoorstel. (2003-2004). Wetsvoorstel tot wijziging van het gerechtelijk wetboek in verband met bemiddeling. 51 0327/001, 5-6. Parl. St. Kamer.. 


\section{BIJLAGE 1 OVERZICHT VAN AFHANKELIJKE EN ONAFHANKELIJKE VARIABELEN}

\section{AFHANKELIJKE VARIABELEN}

Kennen. Deze variabele geeft aan of de respondent ooit gehoord heeft van professionele echtscheidingsbemiddeling. $66,36 \%$ van de respondenten heeft reeds gehoord van bemiddeling $(1=\mathrm{ja})$ ten opzichte van $33,64 \%$ ( $0=$ nee) .

Gebruiken. In de SiV vragenlijst wordt expliciet gevraagd of er naar aanleiding van de echtscheiding een professionele echtscheidingsbemiddelaar werd bezocht. Deze vraag wordt enkel gesteld aan de respondenten die bemiddeling kennen ( $N=1152)$. 20,5\% van deze respondenten geeft aan een bemiddelaar te hebben bezocht terwijl $79,5 \%$ dit niet heeft gedaan.

\section{ONAFHANKELIJKE VARIABELEN}

\section{- ReLATIEKENMERKEN VOOR DE SCHEIDING}

Leeftijd. De leeftijdsvariabele geeft de leeftijd van de respondent op het tijdstip van het definitief apart gaan wonen. Het is vaak onduidelijk wanneer ex-koppels juist in bemiddeling zijn gegaan. Daarom gaan we ervan uit dat er vanaf de feitelijke scheiding beslissingen zullen worden genomen aangaande de echtscheidingsprocedure. Dit houdt onder meer de beslissing tot het al dan niet volgen van bemiddeling in.

Geluk. Het geluk in het jaar voor het definitief apart gaan wonen van de respondent wordt aangegeven door een tienpuntenschaal gaande van ongelukkig (score 1) tot perfect gelukkig (score 10).

Ouderlijke scheiding. Deze onafhankelijke variabele geeft aan of de ouders van de respondent reeds gescheiden waren voordat het ex-koppel definitief apart is gaan wonen. Gegevens over de huwelijkssituatie van de ouders van de ex-partner zijn niet beschikbaar.

\section{- SOCIAALECONOMISCHE KENMERKEN}

Opleidingsniveau van de respondent. Deze informatie wordt weergegeven in drie categorieën aan de hand van het hoogst behaalde diploma. Lager opgeleiden zijn diegenen met hoogstens een diploma lager secundair onderwijs. Categorie twee zijn de respondenten met een diploma van hoger secundair onderwijs. Hoger opgeleiden hebben een diploma van het voortgezet onderwijs.

Opleidingsniveau van de man. Het betreft de man uit de voormalige partnerrelatie ongeacht of dit de respondent of de ex-partner van de respondent is. 
Opleidingsniveau van de vrouw. Het betreft de vrouw uit de voormalige partnerrelatie ongeacht of dit de respondent of de ex-partner van de respondent is.

Activiteitsstatus. Dit is de activiteitsstatus van de respondent op het moment van de scheiding. Deze variabele krijgt code 1/0 naargelang men tewerkgesteld was of niet. Omdat deeltijdse arbeid zeer sterk genderselectief bleek, werd ervoor geopteerd geen verder onderscheid te maken binnen de actieven.

\section{- GeZINSKENMERKEN}

Kinderen. De variabele 'kinderen' geeft aan of er al dan niet kinderen aanwezig waren in het referentiehuwelijk.

Eigenaar. Deze variabele bestaat uit twee categorieën die aangeven of de ex-partners een gemeenschappelijke eigendom hadden of niet. Als de woning eigendom is van één van beide partners of zij huurden de woning dan behoren zij tot de categorie 0 'geen gemeenschappelijke eigendom'.

\section{- ReLATIEKENMERKEn NA BIJ SCHEIDING}

Conflictgraad. Dit is de conflictgraad na de beslissing om definitief uit elkaar te gaan. De respondenten konden op een elfpuntenschaal aangeven hoeveel conflict er was tussen hen en de ex-partner gaande van geen conflict (score 0 ) tot zeer veel conflict (score 10).

Communicatie. Deze variabele geeft aan hoe vaak het ex-koppel niet meer met elkaar praatte gedurende het jaar dat zij definitief apart zijn gaan wonen. De respondenten konden tussen 7 opties kiezen gaande van nooit (score 1) tot dagelijks (score 7). Deze variabele werd gehercodeerd naar 3 categorieën. In categorie 1 "Goede communicatie" werd de oorspronkelijke score 1 (nooit) overgenomen. Categorie 2 "matige communicatie" zijn de respondenten die aangaven maximum één keer per maand niet meer met elkaar te praten. De laatste categorie "slechte communicatie" gaat dan van verschillende keren per maand tot dagelijks de communicatiestroom onderbreken.

Initiatief. Deze variabele geeft aan wie van de ex-partners het initiatief nam om definitief uit elkaar te gaan. De eerste categorie 'beiden' geeft aan dat beiden samen besloten hebben om uit elkaar te gaan. In categorie twee en drie is het respectievelijk de man of de vrouw die besliste om uit elkaar te gaan.

\section{- ECHTSCHEIDINGSREDENEN}

Aan de respondent werden de, maximaal drie, belangrijkste redenen voor het beëindigen van het huwelijk gevraagd. Gebaseerd op de typologie van De Graaf en Kalmijn werden hieruit vijf nieuwe variabelen gehaald die elk telkens één soort emotionele echtscheidingsreden vertegenwoordigen (De Graaf \& Kalmijn, 2006). Ten eerste zijn er de relationele problemen waartoe behoren: niet bij elkaar passen, uit elkaar groeien, tekort aan aandacht, gebrek aan vrijheid, jaloezie, communicatieproblemen en seksuele problemen. Ten tweede zijn er de gedragsproblemen samengesteld uit lichamelijk geweld en verslavingen. Vervolgens is er ontrouw waartoe de respondenten behoren die opgeven dat zijzelf ofwel 
de ex-partner een andere relatie kreeg. De typologie van De Graaf en Kalmijn is echter niet volledig van toepassing op de antwoordcategorieën van de vragenlijst waardoor de laatste twee types (taakverdeling en verschillen in voorkeur) vervangen worden door enerzijds 'problemen met kinderen' en anderzijds 'economische/work-life balance problemen'. De variabele 'problemen met kinderen' krijgt de waarde 1 als de respondenten aangeven dat er een meningsverschil of een probleem was over het krijgen of het opvoeden van de kinderen. Het vijfde en laatste type is dat van de economische problemen waaronder problemen over het uitgavenpatroon, huishoudelijke taakverdeling, financiën en te veel werken behoren. Drie mogelijke antwoorden uit de vragenlijst kunnen niet geplaatst worden in één van bovenstaande categorieën en zullen niet opgenomen worden in de analyse. Het gaat hier over problemen met familie, kennissen of vrienden, seksuele geaardheid en andere redenen.

\section{- COHORT}

Cohort. Er wordt een onderscheid gemaakt tussen koppels die voor (0) of na (1) de wet van juli 2006 definitief apart zijn gaan wonen. 
2014, Vol $4-\mathrm{Nr} 4$

Tabel 3 Beschrijvende statistieken van de onafhankelijke variabelen voor elke afhankelijke variabele.

\begin{tabular}{|c|c|c|c|}
\hline & & Kennen & Gebruiken \\
\hline Opleiding respondent & $\begin{array}{l}\text { Lager of lager secundair } \\
\text { Hoger secundair } \\
\text { Voortgezet }\end{array}$ & $\begin{array}{l}19,43 \% \\
43,83 \% \\
36,74 \% \\
\end{array}$ & \\
\hline Opleiding man & $\begin{array}{l}\text { Lager of lager secundair } \\
\text { Hoger secundair } \\
\text { Voortgezet }\end{array}$ & & $\begin{array}{l}19,90 \% \\
43,02 \% \\
37,09 \%\end{array}$ \\
\hline Opleiding vrouw & $\begin{array}{l}\text { Lager of lager secundair } \\
\text { Hoger secundair } \\
\text { Voortgezet }\end{array}$ & & $\begin{array}{l}18,28 \% \\
40,03 \% \\
41,69 \%\end{array}$ \\
\hline Activiteit & $\begin{array}{l}\text { Inactief } \\
\text { Actief }\end{array}$ & $\begin{array}{l}8,83 \% \\
91,17 \% \\
\end{array}$ & $\begin{array}{l}8,49 \% \\
91,51 \% \\
\end{array}$ \\
\hline Conflict & Gemiddelde & 5,07 & 5,21 \\
\hline Communicatie & $\begin{array}{l}\text { Goed } \\
\text { Matig } \\
\text { Slecht }\end{array}$ & $\begin{array}{l}29,58 \% \\
25,53 \% \\
44,89 \% \\
\end{array}$ & $\begin{array}{l}27,46 \% \\
26,85 \% \\
45,68 \% \\
\end{array}$ \\
\hline $\begin{array}{l}\text { Echtscheidingsredenen } \\
-\quad \text { relatieproblemen }\end{array}$ & Ja/nee & $71,68 \% / 28,32 \%$ & $74,74 \% / 25,26 \%$ \\
\hline - gedragsproblemen & Ja/nee & $14,74 \% / 85,26 \%$ & $14,15 \% / 85,85 \%$ \\
\hline - economische reden & Ja/nee & $25,56 \% / 74,44 \%$ & $26,04 \% / 73,96 \%$ \\
\hline - ontrouw & Ja/nee & $42,03 \% / 57,97 \%$ & $41,15 \% / 58,85 \%$ \\
\hline - $\quad$ probl. met kinderen & Ja/nee & $10,25 \% / 89,75 \%$ & $11,11 \% / 88,89 \%$ \\
\hline - overige & Ja/nee & $13,36 \% / 86,64 \%$ & $13,11 \% / 86,89 \%$ \\
\hline Kinderen & $\begin{array}{l}\text { Geen kinderen } \\
\text { Kinderen }\end{array}$ & $\begin{array}{l}17,27 \% \\
82,73 \% \\
\end{array}$ & $\begin{array}{l}16,06 \% \\
83,94 \% \\
\end{array}$ \\
\hline Eigenaar & $\begin{array}{l}\text { Niet samen } \\
\text { Samen }\end{array}$ & $\begin{array}{l}28,97 \% \\
71,03 \% \\
\end{array}$ & $\begin{array}{l}26,63 \% \\
73,37 \% \\
\end{array}$ \\
\hline Initiatief & $\begin{array}{l}\text { Beiden } \\
\text { Man } \\
\text { Vrouw }\end{array}$ & & $\begin{array}{l}21,63 \% \\
30,93 \% \\
47,44 \%\end{array}$ \\
\hline Leeftijd bij scheiding & Gemiddelde & 37,37 & 37,53 \\
\hline Geluk & Gemiddelde & 2,92 & 2,86 \\
\hline Ouderlijke scheiding & $\mathrm{Ja} /$ nee & $13,23 \% / 86,77 \%$ & $12,74 \% / 87,26 \%$ \\
\hline \multirow[t]{2}{*}{ Cohort } & Voor / Na & $78,50 \% / 21,50 \%$ & $77,89 \% / 22,11 \%$ \\
\hline & $\mathrm{N}$ & 1737 & 1152 \\
\hline
\end{tabular}




\section{ENGLISH ABSTRACT}

Since 2001, professional divorce mediation is legally recognized as a possible part of a divorce procedure. Based on data from the study "Divorce in Flanders" we examine who is aware of the possibility of mediation and who is using it. We highlight the amendment of 18 July 2006 that obligates the judge to inform parents who are divorcing about the possibility of professional divorce mediation. The results show us that higher educated persons have more knowledge about professional divorce mediation. The use of professional divorce mediation subsequently comes more than average when the wife of the ex-couple is higher educated. Moreover, the target group of the amendment of 18 July 2006 is reached. After the amendment, parents are better informed about the possibility of divorce mediation than other divorcing couples. Given a clear effect of the provision of information by judges on the knowledge and also on the use of mediation for this target group, it seems appropriate to generalize the obligation to inform about this specific procedure. Furthermore it's important to integrate professional divorce mediation as one alternative in a wide range of relevant organizations so individuals can reach an informed decision as well as a high quality divorce trajectory.

Keywords: Professional Divorce mediation, mediation, divorce, divorce procedure 